\title{
Correction to: Fast and accurate pseudoinverse with sparse matrix reordering and incremental approach
}

\author{
Jinhong Jung ${ }^{1} \cdot$ Lee Sael $^{2}$ (D) \\ Published online: 22 January 2021 \\ (c) The Author(s) 2021
}

\section{Correction to: Machine Learning (2020) 109:2333-2347 https://doi.org/10.1007/s10994-020-05920-5}

The article [Fast and accurate pseudoinverse with sparse matrix reordering and incremental approach], written by [Jinhong Jung and Lee Sael], was originally published Online First without Open Access. After publication in volume [109], issue [12], pages [2333-2347] the author decided to opt for Open Choice and to make the article an Open Access publication. Therefore, the copyright of the article has been changed to (C) [The Author(s)] [2020] and the article is forthwith distributed under the terms of the Creative Commons Attribution.

\section{Open Access}

This article is licensed under a Creative Commons Attribution 4.0 International License, which permits use, sharing, adaptation, distribution and reproduction in any medium or format, as long as you give appropriate credit to the original author(s) and the source, provide a link to the Creative Commons licence, and indicate if changes were made. The images or other third party material in this article are included in the article's Creative Commons licence, unless indicated otherwise in a credit line to the material. If material is not included in the article's Creative Commons licence and your intended use is not permitted by statutory regulation or exceeds the permitted use, you will need to obtain permission directly from the copyright holder. To view a copy of this licence, visit http://creat ivecommons.org/licenses/by/4.0/.

The original article has been corrected.

The original article can be found online at https://doi.org/10.1007/s10994-020-05920-5.

Lee Sael

sael@ajou.ac.kr

Jinhong Jung

jinhongjung@jbnu.ac.kr

1 Jeonbuk National University, 567 Baekje-daero, Deokjin-gu, Jeonju 54907, Republic of Korea

2 Ajou University, 206 Worldcup-ro, Yeongton-ju, Suwon 16499, Republic of Korea 
Publisher's Note Springer Nature remains neutral with regard to jurisdictional claims in published maps and institutional affiliations. 